\title{
Technique of blind tracheal intubation in rabbits (Oryctolagus cuniculi) supported by previous maneuver of esophageal cannulization ${ }^{1}$
}

\author{
Técnica de intubação traqueal às cegas em coelhos (Oryctolagus cuniculi) auxiliada por prévia \\ manobra de canulização esofágica
}

\begin{abstract}
Suyiene Cordeiro FalcãoI, Júlio Rodrigues Pereira Junior ${ }^{\mathrm{II}}$, Antônio Roberto de Barros Coelho ${ }^{\mathrm{III}}$
${ }^{1}$ Research performed at the Nucleus of Experimental Surgery, Department of Surgery, Federal University of Pernambuco (UFPE), Recife-PE, Brazil. Part of a project approved by FACEPE for scholarship researcher staying of the first author.

${ }^{\mathrm{I}} \mathrm{PhD}$, Veterinary Science,y Federal Rural University of Pernambuco. Fellow, Foundation of Help to Science and Technology of the State of Pernambuco (FACEPE), Recife-PE, Brazil. Main author. Responsible for conception, design, intellectual and scientific content of the study.

II Fellow PhD degree, Postgraduate Program, Veterinary Science, Federal Rural University of Pernambuco, Recife-PE, Brazil. Responsible for anesthesiogical procedures and manuscript writing.

${ }^{\text {III }} \mathrm{PhD}$, Associate Professor and Coordinator of Nucleus of Experimental Surgery, Department of Surgery, UFPE, Recife-PE, Brazil. Tutor. Responsible for intellectual and scientific content of the study, critical revision.
\end{abstract}

\section{ABSTRACT}

PURPOSE: To describe and evaluate a modified technique of blind orotraqueal intubation in rabbits, by supporting of previous cannulization of the esophagus.

METHODS: Twelve New Zealand rabbits, weighing between 2,780 a 4,140 kg were anesthetized with xilazine (3mg/Kg) and ketamine $(20 \mathrm{mg} / \mathrm{Kg})$. The animals were positioned in ventral decubitus with the head hyperextend. With one of the hands the anesthetist with the index and thumb fingers positioned in the labial fissures carry on the opening of animal oral cavity. The esophagus was previously cannulized with a tube \# 3.5 (3.5mm ID), obstructing its lumen. The trachea lumen was intubated with a probe \# 2.5 (2.5mm ID). The positioning of the probe was confirmed through the oscillatory movement of a gauze filament put at outside extremity of tube, resulting from the inspiratory and expiratory flow.

RESULTS: The success index was of $100 \%$.

CONCLUSIONS: This technique is of easy execution, high success index, sparing the use of several devices for visualization of the larynx and glottis. No complications were observed. It also serves for short period training of human resources.

Key words: Intubation, Intratracheal. Technique. Rabbits.

\section{RESUMO}

OBJETIVO: Descrever e avaliar uma técnica modificada de intubação orotraqueal às cegas em coelhos, com auxílio de canulização prévia do esôfago.

MÉTODOS: Doze coelhos da raça Nova Zelândia, pesando entre 2,780 a 4,140 kg foram anestesiados com xilazina (3mg/kg) e Cetamina $(20 \mathrm{mg} / \mathrm{kg})$. Os animais foram colocados em decúbito esternal com a cabeça hiper-estendida. Com uma das mãos o anestesista posiciona o dedo indicador e polegar nas comissuras labiais para abertura da cavidade oral do animal. O esôfago foi previamente canulizado com sonda oㅜ 3,5 (3.5 mm DI), obstruindo sua luz. A traquéia foi entubada com sonda no 2,5 (2.5 mm DI). O posicionamento da sonda foi confirmado através do movimento oscilatório de um filamento na de gaze colocado na extremidade externa do tubo, resultante do fluxo inspiratório e expiratório.

RESULTADOS: O índice de acerto foi de $100 \%$.

CONCLUSÕES: Esta técnica é de fácil execução, alto índice de acerto, dispensando o uso de vários dispositivos e equipamentos para visualização da laringe e da glote. Nenhuma complicação foi observada. É também indicada para treinamento de recursos humanos em curto período

Descritores: Intubação Intratraqueal. Técnicas. Coelhos. 


\section{Introduction}

The anatomy of the respiratory system of the rabbit turns difficult the intubation of the trachea. The tongue is very long, possessing in its base a prominence (Lingual torus). The long and cutting teeth and the small dimension of the larynx, hindering the direct visualization of the glottis, are also points of difficulty. In physiologic position the nasofarinx is intimately related with the larynx that forces the animal to breathe by nose $\mathrm{e}^{1-3}$. The hyperextension head and neck allows better alignment of the orofarinx with the trachea, making possible better visualization of the larynx and insertion of the endotracheal probe. With the laryngeal palpation the animal responses with cough and choke, being observed, after intubated, the condensation inside of the tube. In special circumstances the intubations can be made by transtracheal route, being used a catheter as a guide for the endotracheal tube ${ }^{2}$.

The rabbit is one of the species more used for researches. However its use in complex operative procedures is limited by anesthesia problems. Among the laboratory animals rabbits are considered the most difficult for anesthesia, due to the speed of dose/effect responsiveness of the drugs commonly used, the narrow margin of safety between the anesthetic plan and the death, the high susceptibility of breathing stop during the anesthetic procedure and the difficulty of tracheal intubation. In spite of difficulties, the tracheal intubation is necessary when it is intended to obtain adequate lung ventilation during the operative procedure $^{2,3}$.

Several intubations techniques have been described in the literature, such as: orotracheal or nasotracheal blind intubation ${ }^{4,5}$, intubation through otoscope or laryngoscope ${ }^{3,4}$, intubation through tracheostomy $^{6,7}$, retrograde intubation; intubation through endoscope (fiber optic) $)^{1,2}$ and lung ventilation with devices as Laryngeal Airway Mask (LAM) and Laryngeal Device (AD) ${ }^{9,10}$.

In the present study it is proposed a technique of blind orotraqueal intubation with support of previous canulization of the esophagus, that spares onerous equipments or devices and demands short training period, for use both in Experimental Surgery and Clinical Veterinary Surgery.

\section{Methods}

The experiments were driven in agreement with recommendations of Ethic Commission on Animal Research of Federal University of Pernambuco (CEEA-UFPE).

It was used 12 rabbits of the New Zealand race, of both sexes, weighing between 2.780 and $4.140 \mathrm{~kg}$, originating from commercial supplier and lodged in the vivarium of the Nucleus of Experimental Surgery of the Federal University of Pernambuco. The animals were treated for worms and were fed with specific food for rabbits as well water ad libitum.

The rabbits were submitted previously to a fasting time of $4: 00 \mathrm{~h}$ and then anesthetized with xilazine $(3 \mathrm{mg} / \mathrm{Kg})$ and ketamine $(20 \mathrm{mg} / \mathrm{kg}) \mathrm{IM}$. The hydration was accomplished with physiologic solution to $0.9 \%$, at slow dropping through the marginal vein of the left ear, with a catheter \# $24 \mathrm{G}$.

\section{Intubation technique}

With animals under anesthesia they were positioned in ventral decubitus, with hyper-extended head. With indicator and thumb fingers inserted in the labial commissure to open up the mouth, a tracheal cannula \# 3.5 (3.5mm ID) was inserted in the esophagus with the purpose of obstructing it, being verified it's positioning through the immobility of a gauze filament fixed at free extremity of the cannula (Figure 1). Further, it was proceeded the intubation of trachea with a probe \# 2.5 (2.5 mm ID), taking advantage of the inspiration period. The correct placement of the tube was confirmed through a gauze filament put in the external extremity of the probe, watching its oscillatory movement correspondent to the inspiratory and expiratory flows, as well as for the condensation of the inner surface of probe wall (Figure 1). Then, after confirm the intubation of the airway cannula, it is withdraw the esophagus tube, leaving the tracheal probe for connection the animal to a Baraka anesthesia system with two $\mathrm{T}$ connectors, one for expiratory valve and the other for gas administration. 

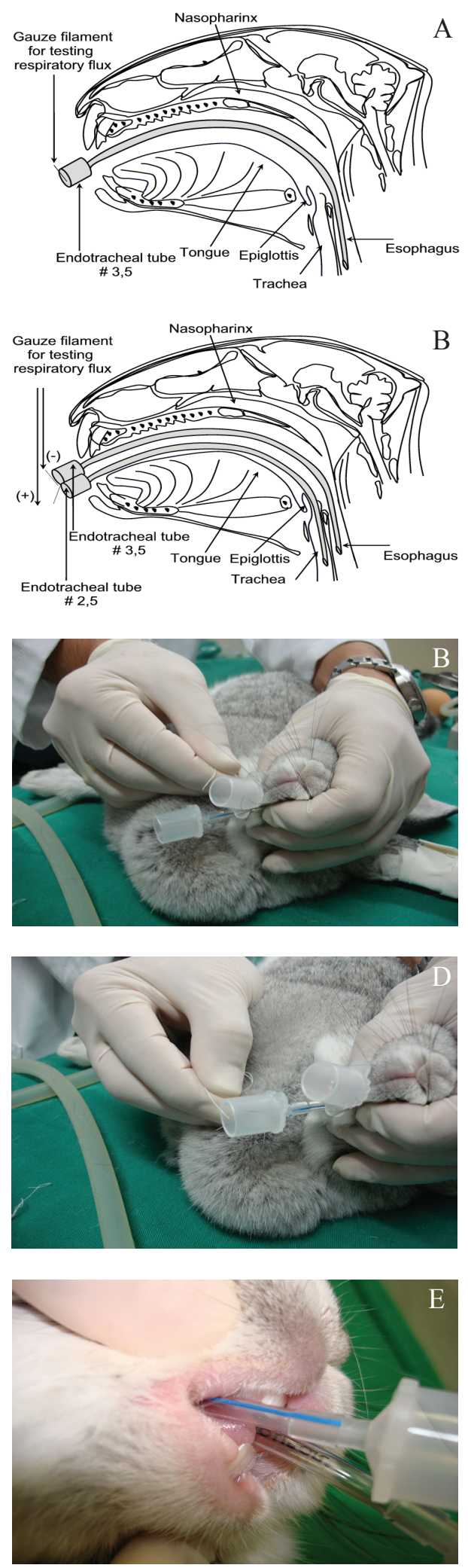

FIGURE 1 - A and B. Previous canulization of the esophagus, being observed the immobilization of the gauze filament. $\mathbf{C}$ and $\mathbf{D}$. Tracheal intubations, being observed displacement of gauze filament, corresponding to the expiratory flow as compared with gauze filament immobilization at the esophagus cannula. A and C. Note that the connector of the tracheal probe is at the level of superior incisive teeth of the animal. E. Condensation inside surface of the probe (black arrow).

\section{Results}

The results showed an index of success of 100\% (Table 1). In no case it was observed complications such as trauma, laryngeal spasm, hemorrhages or postoperative breathing failure.

TABLE 1 - Percentile of success and failure of tracheal intubation with previous esophageal cannulation.

\begin{tabular}{cccc}
\hline $\begin{array}{c}\text { ANIMAL } \\
\text { NUMBER }\end{array}$ & $\begin{array}{c}\text { WEIGHT } \\
(\mathbf{k g})\end{array}$ & SUCCESS & FAILURE \\
\hline $\mathbf{0 1}$ & 3.490 & + & - \\
$\mathbf{0 2}$ & 3.630 & + & - \\
$\mathbf{0 3}$ & 3.552 & + & - \\
$\mathbf{0 4}$ & 3.890 & + & - \\
$\mathbf{0 5}$ & 3.528 & + & - \\
$\mathbf{0 6}$ & 3.460 & + & - \\
$\mathbf{0 7}$ & 2.870 & + & - \\
$\mathbf{0 8}$ & 3.797 & + & - \\
$\mathbf{0 9}$ & 3.957 & + & - \\
$\mathbf{1 1}$ & 4.140 & + & - \\
$\mathbf{1 2}$ & 3.390 & + & - \\
$\mathbf{1 3}$ & 2.780 & + & $\mathbf{0 \%}$ \\
TOTAL & $\mathbf{M}=\mathbf{3 . 8 3 6}$ & $\mathbf{1 0 0 \%}$ & \\
\hline
\end{tabular}

\section{Discussion}

The blind intratracheal intubation technique presumes non visualization of the structures of larynx and glottis. In the present study previous intubation of the esophagus was accomplished with objective of obstructing one of the holes of the orofaringe, facilitating tracheal intubation. The blind technique has been criticized by demanding the presence of spontaneous breathing from the animal, constituting the apnea a problem that implies restriction for the success of this method in rabbits ${ }^{3}$. However, it is one of the most used techniques because its practical executability, being requested larger sensibility of the anesthetist. Ventral, dorsal or lateral decubitus can be used depending on the operator's easiness and preference, since alignment of the trachea and larynx is reached by hyperextension of cephalic segment, to facilitate intubation ${ }^{8}$.

Independent of the technique, tracheal intubation has been confirmed by the natural breathing, auscultation of the breathing sounds, condensation of the air in metallic structures and inside of the intratracheal tube as well by movement of the tórax ${ }^{2-6,8,11,12}$. In the proposed work the flow of expired air flux was observed through oscillatory movements of a gauze filament positioned at the out extremity of the intracheal tube. 
The intubation has been tried with use of devices as otoscope or a number one straight sheet laryngoscope ${ }^{4}$ for partial visualization of the larynx and glottis. It has been reported difficulties in visualization as well as facilitation of trauma occurrence in the oral cavity and in the larynx due to the size of the used instruments, even with the careful manipulation of the intratracheal tubes and procedures adopted by almost consulted authors. It has been recommended, as an important the previous action, the use of sedation to avoid abrupt movements and stress of the animals.

As a preventive way, during the procedures, antiinflammatory agent was used to minimize possible traumatic consequences of three intubation attempts tried in the present work.

The use of techniques as tracheostomy ${ }^{6,7}$ or cricotireoidectomy ${ }^{11}$ was avoided as intubation method, since they are invasive, becoming stress factors in the postoperative, favoring the increase of the risk for anesthetic problems as apnea or laceration of the tracheal structures, as well as for the possibility of carrying resident microorganisms from skin to the airway .

The anesthetic protocol was chosen aiming at a safer and smaller cost procedure. The choice of the proposal technique, among the several techniques for intubation of rabbits previously mentioned in the literature, took into account the following requirements: minimum trauma and invasiveness, easiness manipulation, execution by just one operator, minimization of leak of air between the trachea and the intubation device, trying to adjust its dimension to the tracheal diameter. Even so, every intubation process has complications risk, demanding expertise anesthetist.

The nasotracheal intubation is a blind intratracheal technique that can be used with easiness and with low trauma index, but it has as disadvantage induction of laryngeal spasm, need of high flow of oxygen $(3 \mathrm{~L} / \mathrm{min})$ due to the small diameter of the inserted probe. It still exists the possibility of the probe to constitute a way of introduction of pathogens microorganisms in the airway and lungs, however, in an accomplished study, usual flows of $1.5 \mathrm{ml} / \mathrm{min}$. were obtained and clinical signs of breathing disease were not observed ${ }^{5}$.

With the use of fiber optic endoscope, it has been possible the visualization of larynx and glottis and introduction of intratracheal probes without cuff, through a guide, providing larger rigidity to the tube and facilitating the directionality of its extremity to the glottis. The correct positioning of the tube was confirmed by two methods: direct visualization through the endoscope and presence of condensed air inside the probe during the expiratory flow. The success of the intubation was of $100 \%$, becoming intubation under endoscopy a superior to all the other methods, because the tube is put directly inside of the tracheal lumen, under vision ${ }^{1,2}$.

It has been suggested that the facial mask could be better than the intratracheal intubation in small animals, because this last one can be troublesome, above all for the possibility of occurrence of laryngeal and tracheal injury. However, the facial mask can presents difficulty in provide assisted ventilation and propitiate a larger dead space 9 .

In a comparative work between the use of facial mask and laryngeal mask it was concluded that it is possible to use laryngeal mask to produce normal ventilation and intermittent positive pressure breathing (IPPB). However, the use of this modality can be associated with laryngeal leak of anesthetic gas and gastric tympanism, being ended that additional works would be need to be accomplished with this technique before recommend it for routine use in rabbits ${ }^{13}$.

Intratracheal pediatric tubes with and without cuff were compared with the laryngeal mask in relation to the easiness of use of those devices in rabbits and its capacity of limiting the leak of anesthetic gas. The results indicated that the three devices can be used in rabbits, but the laryngeal mask presents a larger amount of wasted anesthetic gas due to its leakage ${ }^{14}$.

The use of device for airway (Airway Device-AD) presents some negative characteristics such as: obstruction of airway with the extremity of $\mathrm{AD}$ that happens when the tube is positioned incorrectly or accidentally moved. Compared with intratracheal tube, the device $\mathrm{AD}$ and the laryngeal mask were less desirable for animals in which there is regurgitation risk, vomits, blood or foreign body in the superior airway ${ }^{10}$.

All intubation techniques presented possess advantages and disadvantages, therefore, precautions are necessary with the purpose of preventing complications. The intratracheal intubation for general anesthesia has been indicated in small animals, because it offers some advantages on the traditional use of the facial mask, such as: mechanical ventilation possibility, capnografy and apnea alarm use, as well as other monitorization parameters, besides constituting an elementary condition for maneuvers of pulmonary resuscitation ${ }^{2}$.

The intratracheal tube avoids the occurrence of aspiration of the gastric content, saliva, blood and it makes possible the accomplishment of surgeries of the oral cavity, face and thorax, as well as allowed access to the trachea for diagnosis, therapeutics and researches, in face of those benefits. Repeated attempts of intubation can prolong the anesthesia and may result in lesions of 
the glottis as; edema, spasms and perforations. The animal must be intubated in the smallest possible time. When there is trauma evidence the action should discontinue. Injury of the tracheal mucous membrane, due to intubation has been admitted as cause of tracheal narrowing in rabbits and ferrets ${ }^{2}$.

The intratracheal intubation demands close observation during and after the procedure, because the head and neck manipulation can provoke accidental extubation. The intubation provides a satisfactory anesthesia, but creates a potential for severe problems as obstruction of the intratracheal tube, bronchial intubation and inadvertent extubation, that can happen during and after the anesthetic practices. The endoscopy is a technique that although not accessible for all the professionals, is the more secure method of intubation in small mammals ${ }^{2}$.

In spite of the small number of tested animals, the described method suggests that the previous intubation of the esophagus could have influenced positively to obtain a high index of success without evidence of complications.

\section{Conclusions}

The blind intubation with previous cannulation of esophagus has shown a technique of easy accomplishment, with high success index, and without needing of sophisticated equipments, without trauma occurrence and with appropriate potential for veterinary professionals training without previous experience with anesthesia in this species.

\section{References}

1. Worthley SG, Roque M, Helft G, Soundararajan K, Siddiqui M, Reis ED. Rapid oral endotracheal intubation with a fibre-optic scope in rabbits: a simple and reliable technique. Lab Anim. 2000;34:19901.

2. Johnson DH. Endoscopic intubation of exotic companion mammals. Vet Clin North Am Exot Anim Pract. 2010;13(2):273-89.

3. Fonseca NM, Goldenberg S, Gomes PO, Lima CAP. Anestesia em coelhos. Acta Cir Bras. 1996;11(2):82-4.

4. Lima CA de Paula, Goldemberg S, Fonseca NM, Novo NF, Juliano Y. Avaliação de um sistema circular de anestesia, em ventilação mecânica com pressão positiva intermitente. Anestesia quantitativa em coelhos (Oryctolagus cuniculus). Acta Cir Bras. 1996;11(3):10815 .

5. De Valle JMS. Successful management of rabbit anesthesia through the use of nasotracheal intubation. J Am Assoc Lab Anim Sci. 2009;48(3):166-70.

6. Kallas E, Schnaider TB, Juliano Y, Novo NF, Kallas IE, Engelman MFB, Kállas AC, Castro LF. Modelo de anestesia em coelhos para procedimentos no tórax. Acta Cir Bras. 2001;16(2):91-6.

7. Hayashida M, Fukunaga A, Fukuda K, Yamazaki S, Arita H. A rabbit model for evaliation of surgical anesthesia and analgesia: characterization and validation with isoflurane anesthesia and fentanyl analgesia. J Anesth. 2004;18:282-91.
8. Balbinotto RP, Trindade MRM, Meyer FS, Muller ALL, Rosa A Jr, Nunes AG, da Silva R. Anesthesic protocol for videolaparoscopic surgery in rabbits. Acta Cir Bras. 2010;25(1):121-5.

9. Fujita M, Orima H, Simizu, M, Motoyoshi S, Katayama M, Miyasaka K. Use of laryngeal mask airway in small animals. J Vet Med Sci. 1991;53(6):1081-2.

10. Imai A, Eisele PH, Steffey EP. A new airway device for small laboratory animals. Lab Anim. 2005;39:111-5.

11. Morgan TJ, Glowaski M. Teaching a new method of rabbit intubation. J Am Assoc Lab Anim Sci. 2007;46(3):32-6.

12. Fonseca NM, Reis MRC, Fernandes ALM, Rezende ES. Esforço respiratório do coelho com diferentes sistemas de anestesia: $\mathrm{T}$ de Ayre, Bain-Spoerel e Fonseca-Goldenberg. Rev Bras Anestesiol. 1999;49(4):249-56.

13. Bateman L, Ludders JW, Gleed RD. Comparison between facemasck and laryngeal masck airway in rabbits during isoflurane anesthesia. Vet Anaesth Analg 2005;32:280-8.

14. Smith JC, Robertson LD, Auhll A, March, TJ, Derring C, Bolon B. Endotracheal tubes versus laryngeal mask airway in rabbit inhalation anesthesia: ease of use and waste gas emissions. J Am Assoc Lab Anim Sci. 2004;43(4):22-5.

\section{Correspondence:}

Antonio Roberto de Barros Coelho

Rua Galvão Raposo, 234

50610-330 Recife - PE Brasil

Tel: (55 81)3227-0142

arcoelho@globo.com

Received: January 18, 2011

Review: March 22, 2011

Accepted: April 25, 2011

Conflict of interest: none

Financial source: none 